Article

\title{
Efficiency of Mn Removal of Different Filtration Materials for Groundwater Treatment Linking Chemical and Physical Properties
}

\author{
Joanna Jeż-Walkowiak ${ }^{1, *}$, Zbysław Dymaczewski ${ }^{1}$ (D), Agnieszka Szuster-Janiaczyk ${ }^{1}$, \\ Ariadna B. Nowicka ${ }^{2}$ and Mirosław Szybowicz ${ }^{2}$ (D) \\ 1 Instytut Inżynierii Środowiska, Politechnika Poznańska, ul. Berdychowo 4, 60-965 Poznań, Poland; \\ zbyslaw.dymaczewski@put.poznan.pl (Z.D.); agnieszka.szuster-janiaczyk@put.poznan.pl (A.S.-J.) \\ 2 Wydział Fizyki Technicznej, Politechnika Poznańska, ul. Piotrowo 3, 60-965 Poznań, Poland; \\ ariadna.nowicka@put.poznan.pl (A.B.N.); miroslaw.szybowicz@put.poznan.pl (M.S.) \\ * Correspondence: joanna.jez-walkowiak@put.poznan.pl; Tel.: +48-61-665-34-97
}

Received: 30 April 2017; Accepted: 23 June 2017; Published: 8 July 2017

\begin{abstract}
This paper presents research on Fe and Mn removal from groundwater. In treatment systems of aeration followed by rapid filtration (no chemical dosage), manganese removal is possible due to the manganese dioxide catalyst present on the grains of filtration material. The goal of the presented research was to find a correlation between the catalyst layer's composition as well as its internal porosity and the effectiveness and stability of manganese removal in the filtration process. In order to establish the influence of catalyst characteristics on manganese removal effectiveness, the filtration experiment was conducted using filtration materials with catalytic contact layers of different origin. Oxide coated auto-activated silica sand and Gabon manganese ore were tested. Inactive silica sand was used as reference. The results of filtration experiments were combined with analyses of chemical composition, internal porosity, and crystalline parameters of catalyst contact layers of grains. For the determination catalyst contact layer parameters, the following methods were used: Raman spectroscopy, X-ray powder diffractometry (XRD), Scanning Electron Microscope - Energy dispersive spectroscopy (SEM-EDAX), nitrogen adsorption. Pilot scale research on the filtration process demonstrated that auto-activated filtration material was characterized by the highest efficiency of manganese removal and stability of effects during the whole research. The effectiveness of Gabon manganese ore dropped from $90 \%$ and stabilized on the level of ca. $60 \%$ within 15 days of the experiment.
\end{abstract}

Keywords: groundwater; Fe and Mn removal; filtration material; catalyst contact layer; Raman spectroscopy; XRD; EDAX; nitrogen adsorption method

\section{Introduction}

Most groundwaters are contaminated with iron and manganese compounds. Divalent iron and manganese present in groundwater are products of dissolution of simple minerals (e.g., $\mathrm{FeCO}_{3}$, $\mathrm{MnCO}_{3}$, or $\mathrm{FeS}_{2}$ ) in water containing carbon dioxide.

From aesthetic and also health aspects, it is important to meet the standards of iron and manganese concentration in drinking water. Iron and manganese present in water impart a metallic taste and odour, and stain laundry and household fixtures. Precipitates of oxidized iron and manganese compounds in distribution systems can clog pipes and support the growth of iron and manganese bacteria, causing taste and odour problems. The deposition of iron and manganese oxides in distribution systems decreases the diameter of pipes, causing increased headloss, which in turn increases transport costs. In addition to aesthetic and operational problems, the health aspects of manganese content in drinking 
water are of concern. Health effects from over-exposure of iron include Kashin-Beck disease and increased risk of heart disease [1]. Concerning manganese present in water, the nervous system has been determined to be the primary target [2]. There is increasing evidence of neurotoxicity of manganese by the oral route, especially in infants fed with infant formulas containing manganese [3]. Directive 98/83/EC set the maximum level for iron and manganese in drinking water to $0.2 \mathrm{mgFe} / \mathrm{L}$ and $0.05 \mathrm{mgMn} / \mathrm{L}$ [4].

The traditional technology of groundwater treatment consists of aeration followed by rapid filtration and disinfection. The aeration process introduces oxygen into the water, changing its redox condition. In aerobic environments, the iron and manganese can be oxidized to insoluble forms of $\mathrm{Fe}(\mathrm{III})$ an $\mathrm{Mn}(\mathrm{IV})$ compounds. Precipitated solids can be filtered out. The alternative for aeration is chemical oxidation with chlorine, potassium permanganate, or ozone dosage. As an alternative for rapid filtration, the membranes might be of concern in some conditions [5,6]. In aeration-rapid filtration technology, manganese oxidation is an autocatalytic process. The catalyst is a manganese dioxide- the product of Mn(II) oxidation occurring during groundwater treatment. The process of manganese oxidation with use of filtration material is a process of heterogenic autocatalysis. High effects of groundwater treatment are obtained by aeration followed by catalytic oxidation in catalytic-oxidative filtration beds.

When silica sand is used as filtration material, the product of reaction, manganese dioxide, covers the grains, creating during the ripening process the permanent catalytic contact layer capable of adsorbing and catalysing the manganese oxidation. Auto-activated silica sand is a filtration material that offers improvements during the ripening process and it is the most common material used in traditional groundwater treatment systems $[7,8]$.

The ripening of filtration material is often supported with biological oxidation processes [9-13]. Biological groundwater treatment is fundamentally a filtration process that takes advantage of the ability of certain bacteria to oxidize iron and manganese and to assimilate ions. Biological activation of media is also promoted by the porous structure of grains, which facilitates deposition by iron and manganese bacteria, starting the process of activation. Biological processes are important for $\mathrm{Mn}$ removal during the ripening process $[8,10]$. According to previous research, especially in the early stage of filter start-up, biological oxidation of manganese by manganese-oxidizing bacteria enhances filter performance $[8,10]$. After the start-up, when the grains are covered with oxide coatings, the catalytic oxidation of manganese plays the main role in manganese removal [13].

Problems appearing occasionally during auto-activation of silica sand (especially in the case of low manganese concentration in raw water with the result of not enough manganese to create a catalytic layer in a reasonable time of a Water Treatment Plant (WTP) start-up) caused increased interest in natural catalytic filter media (e.g., Pyrolox, Gabon manganese ore) which are often used in smaller groundwater treatment plants. Applying manganese ores allows for the elimination of the ripening period [14]. These media, consisting of up to $90 \%$ of manganese dioxide, are able to catalyse the process of manganese oxidation from the start of operation. The disadvantage of such media is high price and decrease of catalytic activity in time, until they reach the state of dynamic balance, characteristic for certain raw water composition and treatment technology [7].

Research on the properties of the catalytical contact layer of oxidative media are not commonly conducted, even in fundamental work on Fe and Mn removal from groundwater. The need for such research comes from the assumption that properties of catalysers are tied together with the characteristics of the processes of catalytic Fe and Mn removal. We can expect that catalysers of auto-activated sand and natural catalytic filter materials are different in chemical composition, polymorphic form of manganese dioxide, and internal microstructure. These differences affect the stability of Fe and Mn removal efficiency [7,14].

Manganese dioxide, which is a catalyser of the manganese oxidation process, can occur in different polymorphic forms. Oxidation of manganese in water may undergo different pathways. A scheme of the possible pathways of manganese transformations from the bivalent to quadrivalent 
form is given in Figure $1[15,16]$. It is also possible that transitional forms of manganese oxides will appear, like Hausmannite- $\mathrm{Mn}_{3} \mathrm{O}_{4}$. In oxidation products—oxides and dioxides-manganese occurs in different oxidation states. The oxides that come into existence are not in stoichiometric proportions but demonstrate the deficiency of oxygen.

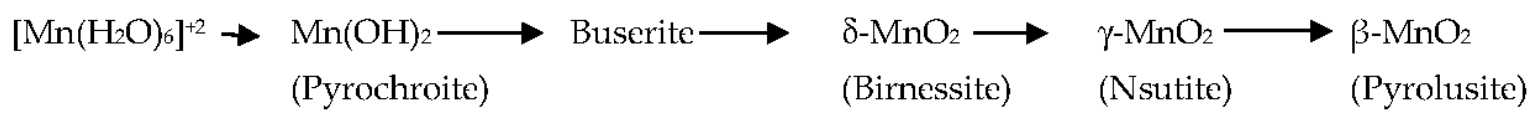

Figure 1. The scheme of transformations of manganese compounds during manganese oxidation in water under heterogenic conditions [16].

The manganese valence in oxides shown in Figure 1 change in the range from 2 (Pyrochroite), through 3.5-3.9 (Buserite/Birnessite) to 4 (Pyrolusite) $[15,16]$. The most stable form of manganese dioxide, occurring naturally, is pyrolusite. This oxide creates a specific layer which coats the grains of the filtration material during the manganese removal process with the use of chemical oxidants or is a component of manganese ore utilised as filtration media in groundwater treatment technology [15]. Pyrolusite is characterised by high adsorption capacity to dissolved Mn(II) but does not have autocatalytical properties [15].

The process of auto-activation without use of chemicals prefers the creation of not fully oxidized forms of manganese oxides, for example, birnessite [7,15]. Birnessite present in the catalyser of the Mn removal zone is the manganese oxide with valence equal to 3.5-3.9. The composition and the structure of this form of manganese oxide results in the birnessite easily entering into redox reactions and taking part in ion exchange. Birnessite is characterised by high adsorption capacity for manganese, providing conditions for further autocatalytic oxidation $[7,15]$.

The surface of catalysers and catalytical filter media, dependent on the $\mathrm{pH}$ value, are characterised by different electrokinetic potential. The values of isoelectric points for quartz and manganese dioxide forms which potentially can be a part of catalysers created on the grains of filtration material as well as build the structure of catalytical layer is shown in Figure 2 and in Table 1 [16-18].

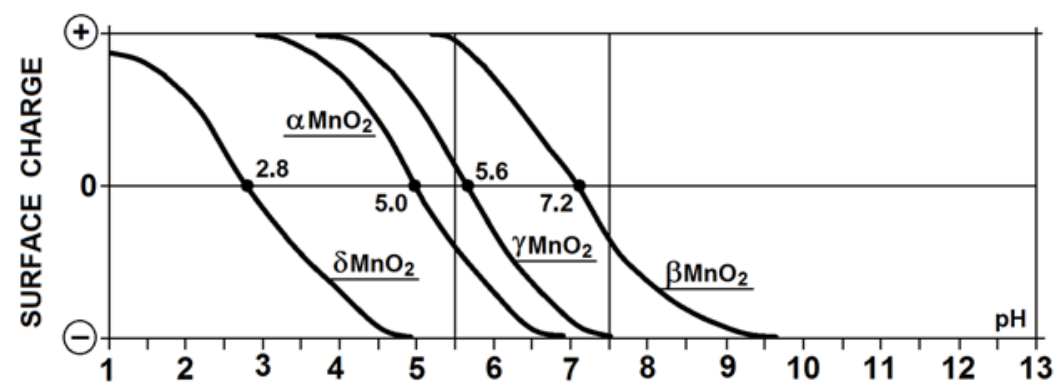

Figure 2. Schematic diagram $\zeta=\mathrm{f}(\mathrm{pH})$ for the surfaces of quartz and of $\mathrm{MnO}_{2}$ and $\mathrm{Fe}_{2} \mathrm{O}_{3}[16,19]$.

Table 1. $\mathrm{pH}$ of the isoelectric points of catalytic materials and $\mathrm{SiO}_{2}$ [17-19].

\begin{tabular}{ccc}
\hline Polymorphic Variant of $\mathbf{M n O}_{2}$ & Formula & $\mathbf{p H}$ of Isoelectric Point \\
\hline Hollandite & $\alpha-\mathrm{MnO}_{2}$ & 5.0 \\
Pyrolusite & $\beta-\mathrm{MnO}_{2}$ & 7.2 \\
Nsutite & $\gamma-\mathrm{MnO}_{2}$ & 5.6 \\
Birnessite & $\delta-\mathrm{MnO}_{2}$ & 2.8 \\
Quartz & $\mathrm{SiO}_{2}$ & 2.0 \\
\hline
\end{tabular}

In natural waters, the surfaces of silica sand grains have negative charge and the isoelectric point exists in the $\mathrm{pH}$ of about 2.0. This causes that the surface of the silica sand grains to have the potential ability for attraction of cations and colloids of $\zeta>0$ (Figure 2). The isoelectric points of the presented 
forms of manganese oxides exist in higher $\mathrm{pH}$. Natural groundwater usually has $\mathrm{pH}$ within the range of 5.5-7.5. In such $\mathrm{pH}$, the forms of manganese oxide also have negative charges on their surfaces and the ability to attract cations. Higher negative charge in lower $\mathrm{pH}$ results in birnessite $\left(\delta-\mathrm{MnO}_{2}\right)$ over the other forms of manganese dioxide.

The effects of auto-activation and adsorption of manganese on the filter bed surface depend on the microstructure of the grains of the filtration material. Measurements of the internal microstructure parameters, such as specific surface and pore volume, allow for the determination of the potential ability of the catalyser for manganese adsorption on its surface, which is necessary for catalytic and heterogenic Mn oxidation [7].

The aim of this work is to establish the characteristics of catalytic contact layers of different origins. One is the contact layer of oxide coated auto-activated silica sand and the other is a natural catalytic material-the Gabon manganese ore. The second goal of this research is to evaluate the influence of catalyst properties on the efficiency and stability of manganese removal from groundwater in the filtration process.

\section{Materials and Methods}

To evaluate the influence of catalysts properties on the effect of groundwater filtration, a series of pilot research was conducted, with the use of $3 \mathrm{~m}$ high filtration columns with diameters of $10 \mathrm{~cm}$. The scheme of the pilot plant is presented in Figure 3. The research installation was supplied with groundwater aerated on full scale aerators of Poznan WTP. During the series of research, six filtration runs were done with a filtration rate of $10 \mathrm{~m} / \mathrm{h}$. Each filtration run lasted for about $60 \mathrm{~h}$.

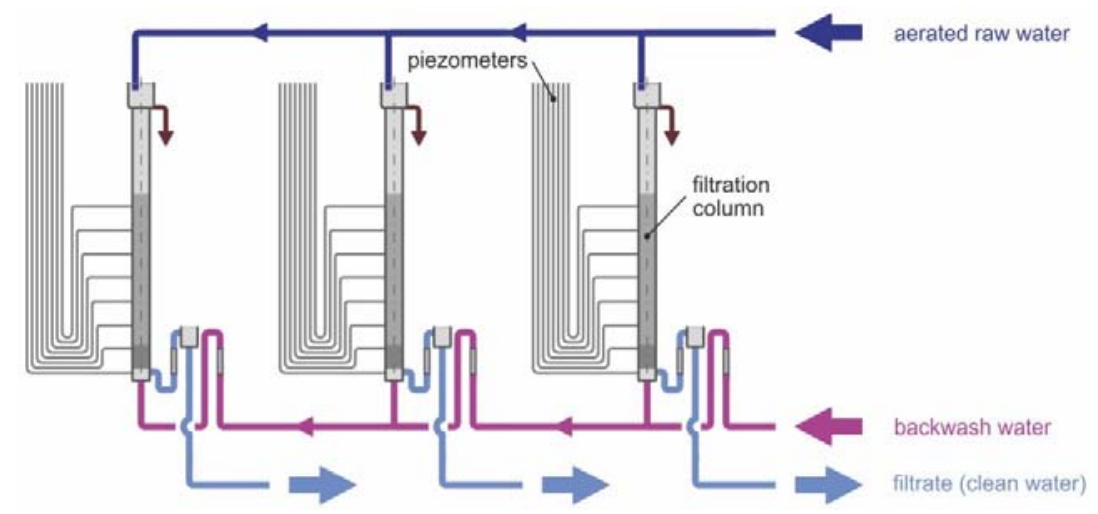

Figure 3. Pilot plant installation.

Filtration was performed parallel through three filtration media:

- auto-activated silica sand (oxide coated filter media),

- Gabon manganese ore,

- clean silica sand.

Auto-activated sand was taken from full-scale filters from WTP where the pilot plant was situated. The media were 10 years old. The Gabon manganese ore was new.

The manganese concentration was measured in the influent and effluent from filtration columns. Water samples were taken four to six times during a day.

To determine the chemical composition of catalysts the energy dispersive spectroscopy-EDAX, coupled with SEM-was used. Weight shares of predominant elements were analysed using Microscope Quanta FEG 250 (FEI) with EDS Octane II Silicon Drift Detector (EDAX).

For the research on the identification of different polymorphic forms of oxides of the investigated catalysts, the method of $\mu$-Raman spectroscopy was used. The non-polarised Raman spectra of filtration materials were recorded in the backscattering geometry using a Via Renishaw micro-Raman 
system. All spectra were recorded in the range of 100 to $2000 \mathrm{~cm}^{-1}$. As an excitation light, the green line of argon laser operating at $5145 \mathrm{~nm}$ (three accumulations of each spectra) was used. A laser beam was focused on the sample through the long working distance of the $50 \times / 0.5$ objective. The spatial resolution of the Raman spectra was about $2 \mu \mathrm{m}$. The power of the laser beam was less than $5 \mathrm{~mW}$. All measurements were performed at room temperature. The crystalline structure of the catalytic contact layer in the manganese removal zone as well as silica sand beds were examined using the method of X-ray powder diffractometry (XRD). Examinations consisted of a comparison of diffraction diagrams obtained in Brucker D8Advance diffractometer for the analysed samples and the reference diagrams available in specialised databases [20]. The internal structure parameters pore volume and specific surface area were determined with the nitrogen adsorption method with a Tristar II 3020 apparatus.

\section{Results and Discussion}

The filtration experiment evaluated manganese removal efficiency of three tested materials. The daily average efficiency of manganese removal E(Mn) was calculated according to Equation (1):

$$
\mathrm{E}=\frac{1}{\mathrm{n}} \cdot \sum_{\mathrm{i}=1}^{\mathrm{n}} \mathrm{E}_{\mathrm{i}}
$$

where:

$$
E_{i}=\frac{\left(c_{\text {in }}\right)_{i}-\left(c_{\text {out }}\right)_{i}}{\left(c_{\text {in }}\right)_{i}} \cdot 100
$$

where $c_{i n}$ and $c_{\text {out }}$ refer concentrations of manganese at the inlet and outlet of the filter, respectively, measured $\mathrm{n}$ times during the day, $\mathrm{mg} / \mathrm{L}$.

The experimental installation was supplied with aerated natural groundwater from the water treatment plant. The raw groundwater quality is presented in Table 2.

Table 2. Raw groundwater quality.

\begin{tabular}{cc}
\hline Water Quality Parameter & Range of Values \\
\hline Manganese, $(\mathrm{mg} / \mathrm{L})$ & $0.2-1.20$ \\
Iron, $(\mathrm{mg} / \mathrm{L})$ & $0.1-1.00$ \\
Alkalinity, $(\mathrm{mval} / \mathrm{L})$ & $3.6-4.0$ \\
Bicarbonate $(\mathrm{mval} / \mathrm{L})$ & $3.6-4.0$ \\
Total hardness, $\left(\mathrm{mgCaCO}_{3} / \mathrm{L}\right)$ & $275-370$ \\
Ammonia, $\left(\mathrm{mgN}^{\prime} \mathrm{L}\right)$ & $0.5-1.0$ \\
Nitrate, $\left(\mathrm{mgN}^{-} \mathrm{L}\right)$ & $0.1-3.0$ \\
$\mathrm{COD} \mathrm{KMnO}_{4}\left(\mathrm{mgO}_{2} / \mathrm{L}\right)$ & $3.0-4.0$ \\
Dissolved $\mathrm{O}_{2}\left(\mathrm{mgO}_{2} / \mathrm{L}\right)$ & $10.0-10.2$ \\
$\mathrm{pH}$ & $7.0-7.4$ \\
Temperature $\left({ }^{\circ} \mathrm{C}\right)$ & $9-10$ \\
\hline
\end{tabular}

The granulometry parameters and filter depth are presented in Table 3.

Table 3. Granulometry parameters and filter depth.

\begin{tabular}{cccc}
\hline Media & $\mathbf{d}_{\mathbf{1 0}}(\mathbf{m m})$ & $\mathbf{d}_{\mathbf{6 0}} / \mathbf{d}_{\mathbf{1 0}}$ & $\mathbf{H}(\mathbf{m})$ \\
\hline Gabon manganese ore & 1.2 & 1.30 & 1.6 \\
Auto-activated silica sand & 1.6 & 1.40 & 1.6 \\
Clean silica sand & 1.3 & 1.25 & 1.6 \\
\hline
\end{tabular}

The efficiency of Fe removal in all filtration cycles for all filtration media was very high, equal to approximately $100 \%$. In Figure 4, the efficiency of manganese removal as a function of total filtration time is presented. The average efficiency of manganese removal in auto-activated silica sand 
was stable, equal to $100 \%$. During the whole experiment, the efficiency of manganese removal in Gabon manganese ore dropped from $90 \%$ to $60 \%$ and stayed stable at this value. As was expected, the efficiency of manganese removal in clean silica sand gradually increased from $20 \%$ to $40 \%$. The silica sand started the ripening process, thus the oxide coat started to develop.

The first stage of research on catalysers was taking photographs of the surfaces of the investigated materials using Raman spectrometer and a scanning electron microscope. The photos allowed for the determination of the colour and texture of the analysed catalysers, which are the following:

- catalyser from upper layer of filter bed-iron removal zone-brown,

- catalyser from lower layer of filter bed-manganese removal zone-dark brown,

- Gabon manganese ore-dark grey,

- quartz-bright yellow.

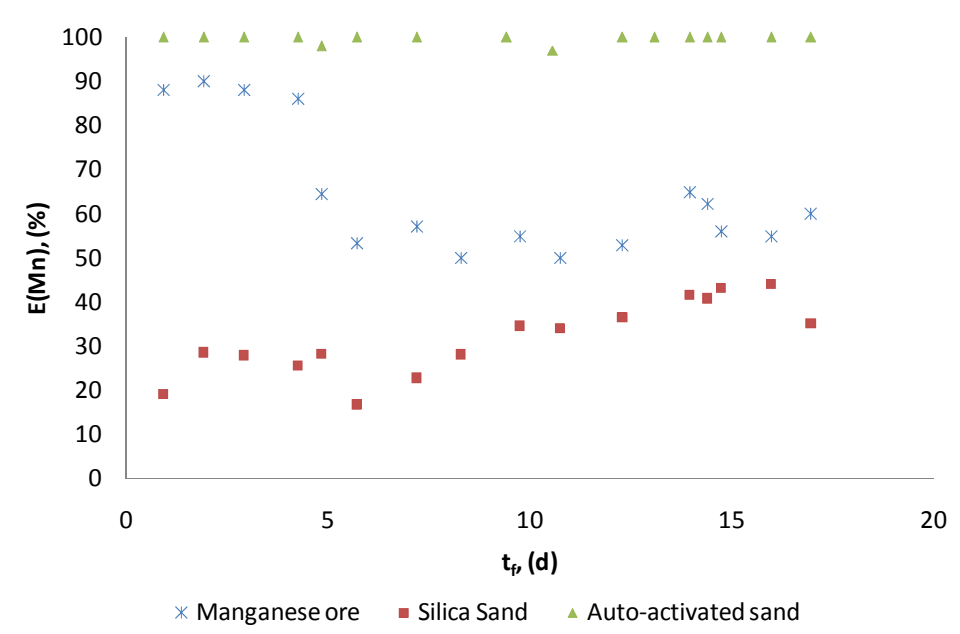

Figure 4. Efficiency of manganese removal in the filtration process through tested beds as a function of total filtration time.

Research conducted using the EDAX apparatus in combination with the electron scanning microscope enabled [21] the determination of the elemental composition in the surface layers of the analysed catalysers and silica sand (Table 4). In this method, patterns of elemental concentrations in the surface layers of catalyser samples were used as well as determined spectra-charts of peaks indicated the number of emitted pulses of Roentgen radiation, characteristic for the specific elements.

Table 4. Weight shares of predominant elements in the investigated filter beds and catalysers.

\begin{tabular}{ccccccccccc}
\hline \multirow{2}{*}{ Investigated Material } & \multicolumn{10}{c}{ Weight Shares of Elements (in \%) } \\
\cline { 2 - 10 } & Fe & Mn & O & Si & Ca & Al & K & S & P \\
\hline Silica sand & 0.17 & - & 60.7 & 37.4 & - & 1.42 & 0.24 & - & - \\
Catalyser-iron removal zone & 29.5 & 18.5 & 46.0 & 1.05 & 3.00 & 0.7 & - & 0.09 & 0.40 \\
Catalyser-manganese removal zone & 15.6 & 21.5 & 55.0 & 0.90 & 2.90 & 3.51 & - & - & 0.21 \\
Gabon manganese ore & 3.66 & 48.95 & 40.6 & 1.84 & - & 2.73 & 1.52 & - & 0.07 \\
\hline
\end{tabular}

The obtained results (Table 4 ) indicate that:

- $\quad$ silica sand can be classified as a chemically homogenous material, where $\mathrm{SiO}_{2}$ is a dominating compound, and aluminium $(1.42 \%)$ is the main additive;

- in the catalyser of iron removal zone, as expected, iron was observed to represent a large portion $(29.5 \%)$ and there was a considerable amount of manganese (18.5\%). The presence of such a large 
amount of oxygen (46.0\%) is because of iron and manganese oxides represent a large proportion of the total mass of the catalyser. Out of the other elements the presence of calcium (3.0\%) was stated.

- in the catalyser of manganese removal zone, $21.5 \%$ was observed to be manganese, with as much as $15.6 \%$ of iron and $2.9 \%$ of calcium. The presence of iron and calcium in this zone decreased catalytical activity in comparison to contact layers with higher Mn content.

- in the Gabon manganese ore, $48.95 \%$ was observed to be manganese, $40.6 \%$ of oxygen, and only $3.25 \%$ iron. Manganese dioxide was then the main constituent of the investigated Gabon manganese ore.

In research on the identification of different particles of the investigated filtration materials (Mn and Fe oxides, silicon oxides), the method of $\mu$-Raman spectroscopy was used. In this method, a comparison of investigated materials spectra and reference spectra is conducted. In Table 5, the values of characteristic wavenumbers for iron, manganese, and quartz oxides present in catalytic coatings are given. These values are the patterns for comparison and for identification of certain polymorphic forms in the investigated materials on the basis of Raman spectra.

The Raman spectra of the measured media-catalysers of iron and manganese removal zones, catalytical filter beds, silica sand-are shown in Figure 5.

The comparison of analysed Raman spectra with the reference values of Raman bands (shown in Table 5) of silica sand chemical composition proved that the basic component is silicon dioxide, so called silica. The Raman spectrum of the silica sand sample presented in Figure 5 has the following Raman bands: $127,206,464 \mathrm{~cm}^{-1}$. The same values of characteristic wavenumbers, which determine the place of Raman bands, can be found in the reference spectrum of quartz (Table 5). The conclusion is that the silica sand used in technological investigations is a filtration material with the structure of pure quartz [20,22].

Table 5. Raman shifts for silica and iron and manganese oxides [15,22,23].

\begin{tabular}{ccccccc}
\hline Compound & \multicolumn{5}{c}{ Wavenumber $\left(\mathbf{c m}^{-\mathbf{1}}\right)$} \\
\hline Quartz, $\mathrm{SiO}_{2}$ & 127 & 206 & 464 & & & \\
Maghemite $\gamma \mathrm{Fe}_{2} \mathrm{O}_{3}$ & 350 & 512 & 665 & 730 & & \\
Hematite $\alpha \mathrm{Fe}_{2} \mathrm{O}_{3}$ & 265 & 300 & $345-395$ & 515 & $645-670$ & 715 \\
Birnessite $\delta-\mathrm{MnO}_{2}$ & $495-505$ & $570-575$ & $635-655$ & & & \\
Pyrolusite $\beta-\mathrm{MnO}_{2}$ & 538 & 665 & & & & \\
Nsutite $\gamma-\mathrm{MnO}_{2}$ & 379 & 491 & 520 & 572 & 631 & 738 \\
Ramsdellite & 294 & 518 & 580 & 630 & 740 & \\
\hline
\end{tabular}

Using the same method of comparison of the Raman spectrum for the iron removal zone with the reference plot of characteristic wavenumbers (Table 5) of iron oxides, the presence of hematite $\alpha \mathrm{Fe}_{2} \mathrm{O}_{3}$ and maghemite $\gamma \mathrm{Fe}_{2} \mathrm{O}_{3}$ was confirmed [22].

In the Raman spectrum of manganese removal zone, the obtained Raman bands have the same wavenumber as in the reference spectrum of birnessite, proving its presence in that catalyser (Table 5, Figure 5). Birnessite is a manganese dioxide that is not fully oxidized $\mathrm{MnO}_{3.5 \div 3.9}[15,23,24]$, and its presence in the catalytic layer of grains which are in the manganese removal zone describes its path of oxidation from two valence Mn to four valence Mn (Figure 1) [16].

A comparison of Raman spectra of Gabon manganese ore and reference spectra demonstrated the presence of manganese dioxide in the form of pyrolusite, ramsdellite, and nsutite (Table 5, Figure 5).

A comparison of the research results on the catalytical layer of the auto-activated filtration bed and Gabon ore showed a more beneficial chemical composition of the first one, which, by the presence of $\mathrm{MnO}_{2}$ in the form of birnessite has more potential for adsorption of manganese and its catalytic oxidation in the auto-activated filtration bed.

The crystalline structure of the catalytical layer in the manganese removal zone as well as silica sand beds were examined using the method of X-ray powder diffractometry (Brucker D8Advance 
diffractometer). Examinations consisted of a comparison of diffraction diagrams of the analysed samples and the reference diagrams available in specialised databases [20].

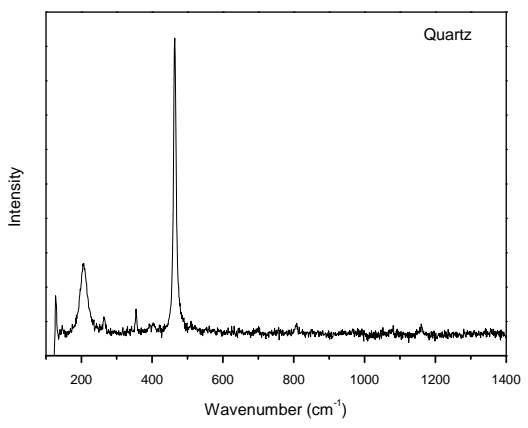

(a)

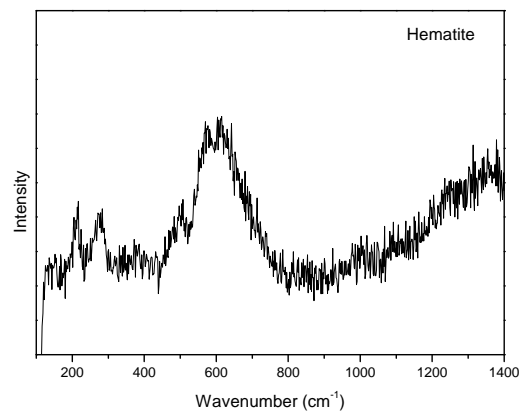

(c)

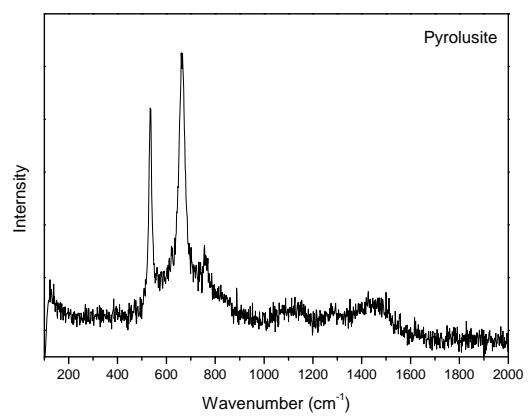

(e)

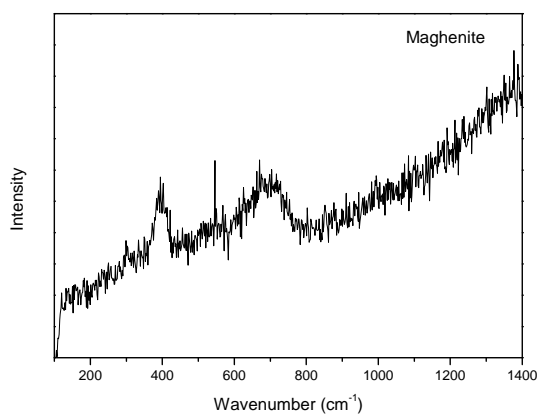

(b)

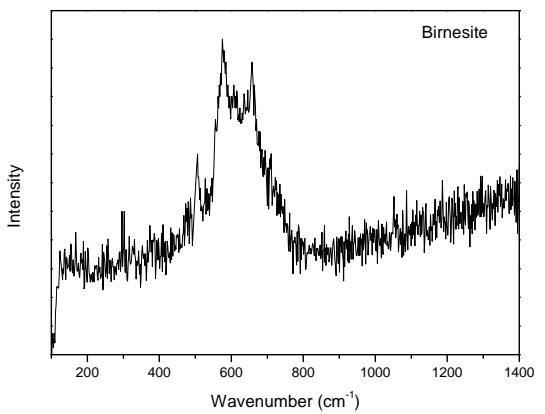

(d)

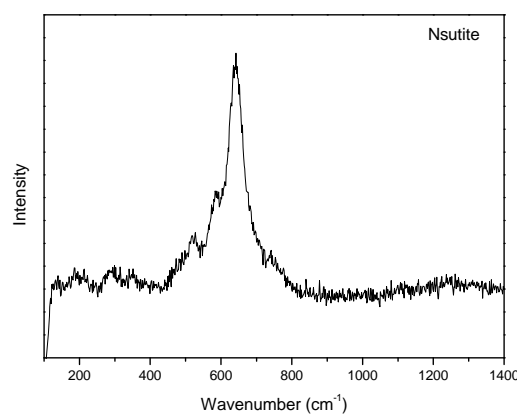

(f)

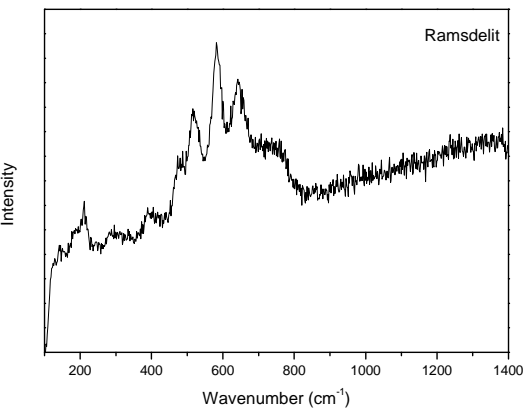

$(\mathrm{g})$

Figure 5. Raman spectra of investigated materials with use of spectroscope Renishaw. (a) Raman spectrum of silica sand; (b,c) Raman spectra of iron removal zone catalyser; (d) Raman spectrum of manganese removal zone catalyser; (e-g) Raman spectra of Gabon manganese ore. 
In Figure 6, diffraction diagrams of catalyser from manganese removal zone of the auto-activated filtration bed, catalytic Gabon Mn, ore as well as clean silica sand are shown.

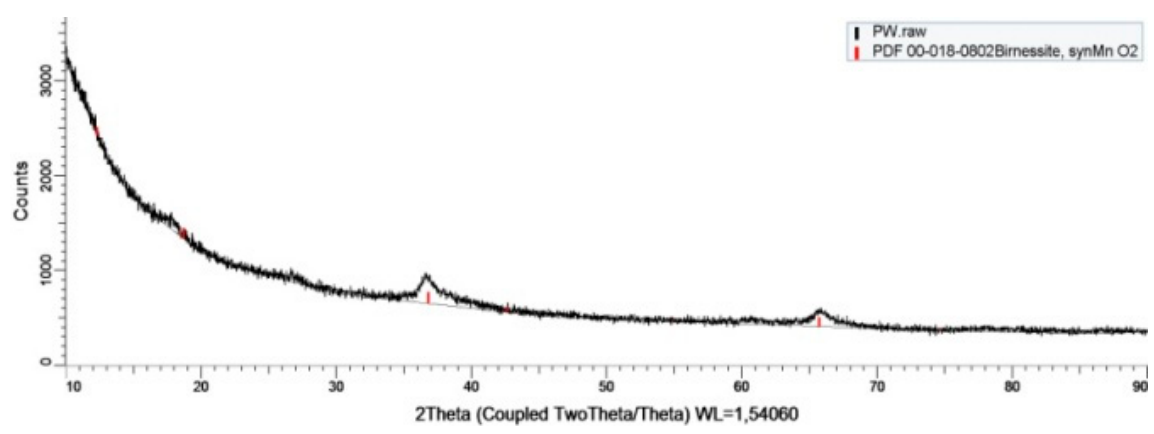

(a)

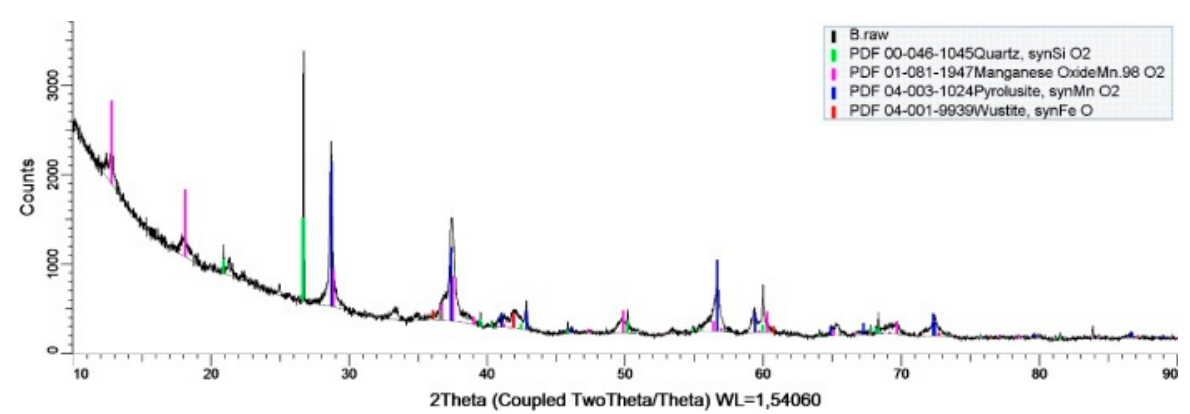

(b)

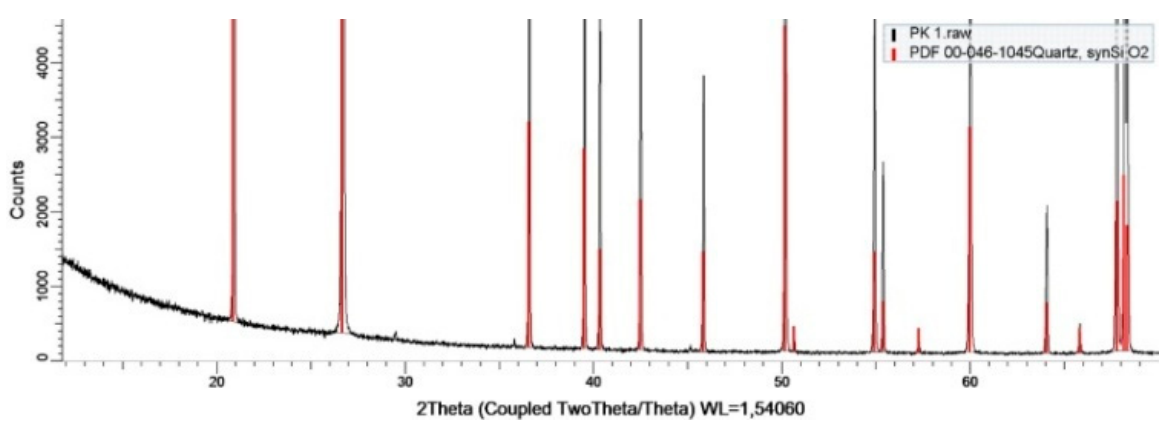

(c)

Figure 6. Diffraction diagrams of catalyser in manganese removal zone, Gabon Mn ore, and clean silica sand. (a) Catalyser of manganese removal zone; (b) Gabon manganese ore; (c) Silica sand.

The diffraction diagram of the sample of catalyser from manganese removal zone, which was collected on the grains of the bottom zone of the filtration bed, and examined using the X-ray diffractometry, indicated the presence of Birnessite. The presence of this form of manganese oxide in the material of catalyser of manganese removal zone was also proved by investigation using Raman spectroscopy, as described earlier in this article (Figure 5). In the sample, some amounts of $\mathrm{Fe}_{3} \mathrm{O}_{4}$ and vaterite- $\mathrm{a}$ form of $\mathrm{CaCO}_{3}$ - were found. The catalyser of the manganese removal zone is a fine-crystalline material.

The Gabon manganese ore is a material of diversified crystallinity, with a mixture of different sized crystallites. Its chemical composition consists of: two predominant forms of manganese dioxide (pyrolusite and $\mathrm{Mn}_{0.98} \mathrm{O}_{2}$ ), iron oxide-Goethite $\mathrm{FeO}(\mathrm{OH})$ (the reference diffraction diagram is identical to Wustite $\mathrm{FeO})$ - and quartz $\left(\mathrm{SiO}_{2}\right)$.

The diffraction diagram of the sample of silica sand indicated the presence of quartz in it. It is the dominating form which is present as crystals in these materials. 
Diffractometric measurements and calculations based on the results of these measurements, as well as on the Scherrer equation, enabled the identification of crystallites of the following size:

- in the silica sand- $-120 \mathrm{~nm}$,

- in catalyser of the manganese removal zone $-8 \mathrm{~nm}$,

- in the Gabon manganese ore- $-\mathrm{Mn}_{0.98} \mathrm{O}_{2}-20 \mathrm{~nm}$, pyrolusite $\left(\mathrm{MnO}_{2}\right)-40 \mathrm{~nm}$, Goethite $\mathrm{FeO}(\mathrm{OH})-30 \mathrm{~nm}$, quartz-130 $\mathrm{nm}$.

An examination of the microstructure parameters of the catalyser of the Mn removal zone, Gabon Mn ore, and clean silica sand was conducted using the method of adsorption and desorption of nitrogen with a Tristar II 3020 apparatus.

The results of nitrogen sorption measurements using Tristar are presented in Table 6.

The results shown in Table 6 indicate the presence of a highly expanded microstructure of a catalytical layer of manganese removal zone. The specific surface area BET (Brunauer, Emmett, Teller isotherm method) of this catalyser, which is equal to $181.5 \mathrm{~m}^{2} / \mathrm{g}$, is 25 times bigger than the specific surface area of manganese ore and almost 3000 times bigger than silica sand. The pore volume is 24 times bigger than the pore volume of the Gabon Mn ore and almost 2000 times bigger than the silica sand. The mean pore width and diameters in the catalyser are comparable to these parameter values in manganese ore and are significantly smaller than in silica sand.

Table 6. Parameter values of the microstructure of the catalyser and filtration beds according to nitrogen sorption measurements.

\begin{tabular}{cccccc}
\hline Material & Specific Surface & Pore Volume & Mean Pore Width (nm) & \multicolumn{2}{c}{ Mean Pore Diameter (nm) } \\
\cline { 5 - 6 } & $\begin{array}{c}\text { Area(BET) }\left[\mathbf{m}^{\mathbf{2}} / \mathbf{g}\right] \\
{\left[\mathbf{c m}^{3} / \mathbf{g}\right]}\end{array}$ & Adsorption (BET) & $\begin{array}{c}\text { Adsorption } \\
\text { (BJH) }\end{array}$ & $\begin{array}{c}\text { Desorption } \\
\text { (BJH) }\end{array}$ \\
\hline Catalyser * & 181.501 & 0.343 & 7.242 & 8.144 & 5.8959 \\
Gabon manganese ore & 7.2514 & 0.0143 & 7.869 & 8.4754 & 5.5892 \\
Clean silica sand & 0.064 & 0.0002 & 12.041 & 14.065 \\
\hline
\end{tabular}

* Catalyser of manganese removal zone of auto-activated silica sand.

The presented results of this research on catalyser's characteristics as well as filtration results give valuable information on the impact of catalyser's structure on the process of catalytical manganese removal from groundwater.

\section{Conclusions}

Experimentally determined properties of tested materials completed the results of the pilot filtration research. The established stability of efficiency of manganese removal is influenced by catalyser characteristics.

Research on the filtration process in the pilot scale through the three tested filtration materials demonstrated that:

- the auto-activated bed was characterized by the highest efficiency of manganese removal and stability of effects during all of the research cycles;

- the Gabon manganese ore was characterized by high ( $90 \%$ ) efficiency of Mn removal from the filtrated water in the beginning of the series of research, but later the effectiveness dropped and stabilized on the level of ca. $60 \%$;

- the silica sand was characterized in the beginning by the lowest Mn removal efficiency (20\%) but observed to increase with time, being subject to the auto-activation process.

The cause of high and stable manganese removal efficiency in the auto-activated bed is due to: 
- the chemical structure and amount of manganese dioxide in the catalyser in the form of birnessite, $\mathrm{MnO}_{1.3 \div 1.9}$-not fully oxidized manganese dioxide. The catalytic layer of manganese removal zone, as a result of the catalyser having a deficiency in oxygen- $\left(\mathrm{MnO}_{\mathrm{x}}(\mathrm{x}=1.3 \div 1.9)\right)$, becomes a semi-conductor, transporting electrons on its surface, which guarantees high efficiency of heterogeneous oxidation reaction. It is related to manganese existence on the catalyser surface for three oxidation numbers, which makes it possible for the catalyser to return oxygen and then associate it again;

- expanded microstructure of the catalytical layer, determined by high values of the specific surface area and pore volume, measured by nitrogen adsorption method using a Tristar II apparatus (catalyser of the manganese removal zone is a material of highly developed microstructure, with a specific surface area of $181.501 \mathrm{~m}^{2} / \mathrm{g}$ and pore volume of $0.343 \mathrm{~cm}^{3} / \mathrm{g}$ );

- the catalyser of the manganese removal zone is a fine-crystalline material, where crystallites are of the size of $8 \mathrm{~nm}$;

- the enhanced cation adsorption properties of birnessite due to a higher negative charge in comparison to other manganese dioxide polymorphic forms at low $\mathrm{pH}$ conditions (Figure 2, Table 1).

Manganese ore contains manganese oxides occurring in the form of ramsdellite, nsutite, and pyrolusite, which have much lower capabilities to catalyse manganese oxidation than birnessite. Manganese ore is a mixture of different sized crystallites. It has a microstructure described by the specific surface area of $7.2514 \mathrm{~m}^{2} / \mathrm{g}$ and pore volume of $0.0143 \mathrm{~cm}^{3} / \mathrm{g}$. These values are much lower than the values determined for the auto-activated catalyser.

Future research should embrace searching for further relationships between the properties and composition of catalysers from one side and technological effects of Fe and $\mathrm{Mn}$ removal from groundwater on the other. In doing so, it will lead to a better understanding of the mechanisms of processes and phenomena taking place during heterogenous, catalytic manganese oxidation in filtration bed, and-in consequence-to intensification of the achieved effects.

Acknowledgments: The authors would like to express their thanks for the financial support from research project 01/13/DSPB/0857.

Author Contributions: J. Jeż-Walkowiak: research concept, conducting and interpretation of results, publication concept and writing; $Z$. Dymaczewski: interpretation of results, publication writing and editing; A. Szuster-Janiaczyk: co-writing publication text; A.B. Nowicka: Raman analyses and interpretation, co-writing publication text; M. Szybowicz: Raman analyses and interpretation, co-writing publication text.

Conflicts of Interest: The authors declare no conflict of interest.

\section{References}

1. Sullivan, J.L. Iron and the Sex Difference in Heart Disease Risk. Lancet 1981, 1, 1293-1294. [CrossRef]

2. United States Environmental Protection Agency. Drinking Water Health Advisory for Manganese; USEPA: Washington, DC, USA, 2004.

3. Hozyasz, K.K.; Ruszczynska, A. High manganese levels in milk-based infant formula. Neurotoxicology 2014, 25, 733. [CrossRef] [PubMed]

4. Drinking Water Directive (DWD). Council Directive 98/83/EC on the quality of water intended for human consumption. Off. J. L 1998, 330, 32-54.

5. Choo, K.-H.; Lee, H.; Choi, S.-J. Iron and manganese removal and membrane fouling during UF in conjunction with prechlorination for drinking water treatment. J. Membr. Sci. 2005, 267, 18-26. [CrossRef]

6. Ellis, D.; Bouchard, C.; Lantagne, G. Removal of Iron and Manganese from Groundwater by Oxidation and Microfiltration. Desalination 2000, 130, 255-264. [CrossRef]

7. Jeż-Walkowiak, J. Wpływ Właściwości Złóż Filtrów Pospiesznych na Efekty Technologii Odżelaziania i Odmanganiania wód Podziemnych; Wydawnictwo Politechniki Poznańskiej: Poznań, Poland, 2016.

8. Jeż-Walkowiak, J.; Dymaczewski, Z.; Weber, Ł. Iron and manganese removal from groundwater by filtration through a chalcedonite bed. J. Water Supply Res. Technol. AQUA 2015, 64, 19-34. [CrossRef] 
9. Buamah, R.; Petrusevski, B.; de Ridder, D.; van de Wetering, T.S.C.M.; Shippers, J.C. Manganese removal in groundwater treatment: Practice, problems and probable solutions. Water Sci. Technol. Water Supply 2009, 9, 89-98. [CrossRef]

10. Bray, R. Role of Microorganisms in Start up Process of Silica Sand for Manganese Removal. In Proceedings of the 2nd Congress of Environmental Engineering, Lublin, Poland, 4-8 September 2005; Volume 32, pp. 155-162.

11. Bray, R.; Olańczuk-Neyman, K. The influence of changes in groundwater composition on the efficiency of manganese and ammonia nitrogen removal on mature quartz sand filtering beds. Water Sci. Technol. Water Supply 2001, 1, 91-98.

12. Mouchet, P. From Conventional to Biological Removal of Iron and Manganese in France. AWWA J. 1992, 84, 158-166.

13. Olańczuk-Neyman, K.; Bray, R. The Role of Physico-Chemical and Biological Processes in Manganese and Ammonia Nitrogen Removal from Groundwater. Pol. J. Environ. Stud. 2000, 9, 91-96.

14. Jeż-Walkowiaki, J.; Dymaczewski, Z. Effectiveness of oxidative filter materials for manganese removal from groundwater. J. Water Supply Res. Technol. AQUA 2012, 61, 364-371. [CrossRef]

15. Bruins, J.H.; Petrusevski, B.; Slokar, Y.M.; Kruithof, J.C.; Kennedy, M.D. Manganese removal from groundwater: Characterization of filter media coating. Desalination Water Treat. 2015, 55, 1851-1863. [CrossRef]

16. Stumm, W.; Morgan, J.J. Aquatic Chemistry, Chemical Equilibria and Rates in Natural Waters, 3rd ed.; Wiley Interscience: Hoboken, NJ, USA, 1996.

17. Kosmulski, M. Surface Charging and Points of Zero Charge; CRC Press; Taylor\&Francis Group: Boca Raton, FL, USA, 2009.

18. Stumm, W. Chemistry of the Solid-Water Interface: Processes at the Mineral-Water and Particle-Water Interface in Natural Systems; John Wiley\& Sons: New York, NY, USA, 1992.

19. Macioszczyk, A. Hydrogeochemia; Wyd. Geologiczne: Warszawa, Poland, 1987.

20. Jędrychowska, S. Możliwości Wykorzystania Spektroskopii Ramanowskiej w Branży Naftowej, cz. I.; Nafta-Gaz: Kraków, Poland, 2012.

21. Anschutz, P.; Dedieu, K.; Desmazes, F.; Chaillou, G. Speciation, oxidation state, and reactivity of particulate manganese in marine sediments. Chem. Geol. 2005, 218, 265-279. [CrossRef]

22. Szybowicz, M.; Koralewski, M. Micro-Raman spectroscopy of natural and synthetic ferritins and their mimetics. Acta Phys. Pol. A 2015, 127, 534-536. [CrossRef]

23. Julien, C.; Massot, M.; Baddour-Hadjean, R.; Franger, S.; Bach, S.; Pereira-Ramos, J.P. Raman Spectra of birnessite manganese dioxides. Solid State Ion. 2003, 159, 345-356. [CrossRef]

24. Julien, C.M.; Massot, M.; Poinsignon, C. Lattice vibration of manganese oxides. Part I Periodic structure. Spectrochim. Acta 2004, 60, 689-700. [CrossRef] 